\title{
PERTUMBUHAN TANAMAN Arachis pintoy YANG DIBERI PERLAKUAN AIR KELAPA DAN PANJANG STEK
}

\author{
C. L. Kaunang dan M. I. Pontoh \\ Fakultas Peternakan Universitas Sam Ratulangi Manado \\ Email: charleslodewijkkaunang@yahoo.com
}

\begin{abstract}
ABSTRAK
Arachis pintoy dapat diperbanyak secara generatif dan vegetatif. Perbanyakan secara vegetatif misalnya penyetekan. Permasalahan yang timbul dari proses penyetekan adalah sulitnya menbentuk akar. Keberhasilan stek membentuk akar tergantung dari besar kecilnya daya pembentukan kallus. Untuk melihat kandungan zat makanan yang terdapat pada batang stek maka dilakukan pemotongan bagian batang. Dengan demikian perlu dicari tambahan faktor lain agar stek cepat membentuk kallus dengan prosentase perakaran yang besar. Salah satu alternatif pemecahannya dengan pemberian air kelapa yang ternyata mengandung berbagai zat makanan dan zat tumbuh. Oleh karena itu dilakukan penelitian untuk melihat interaksi kedua faktor ini terhadap pertumbuhan Arachis pintoy. Maksud dan tujuan penelitian ini adalah untuk mempelajari dan mengetahui pertumbuhan Arachis pintoy yang diberi perlakuan air kelapa dan panjang stek. Penelitian ini telah dilakukan di Laboratorium Agrostologi Kampus Fapet Unsrat Manado, dengan lama penelitian 60 hari. Materi peneltian hijauan Arachis pintoy, air kelapa dan tanah. Sedangkan metode penelitian menggunakan percobaan faktorial dengan 2 faktor A adalah air kelapa dan faktor B adalah stek tanaman Arachis pintoy yang disusun Rancangan Acak Lengkap (RAL). Masing-masing faktor terdiri dari 3 perlakuan dan diulang 3 kali. Faktor tersebut adalah sebagai berikut:Faktor A = ukuran air kelapa A1 = $100 \mathrm{ml}$ air kelapa; A2 $=200 \mathrm{ml}$ air kelapa; dan A3 = $300 \mathrm{ml}$ air kelapa sedangkan Faktor B = Panjang stek Arachis pintoy ; $\mathrm{B}_{1}=10 \mathrm{~cm} ; \mathrm{B}_{2}=15 \mathrm{~cm}$ dan $\mathrm{B}_{3}=20 \mathrm{~cm}$. Variabel yang diukur pada penelitian ini adalah tinggi tanaman, pertambahan jumlah daun, berat kering akar dan volume akar. Hasil penelitian menunjukan bahwa pemberian air kelapa dan panjang stek serta interaksi kedua faktor memberikan pengaruh yang nyata $(\mathrm{P}<0.05)$ terhadap pertumbuhan jumlah daun dan berat kering akar tanaman Arachis pintoy. Selanjutnya air kelapa tidak memberikan pengaruh terhadap volume akar serta kombinasi kedua faktor tidak memberikan pengaruh terhadap pertumbuhan tinggi tanaman. Dari analisa data dan pembahasan untuk semua variabel pada penelitian inidapat disimpulkan kombinasi yang terbaik untuk pertumbuhan jumlah daun, berat kering akar dan volume akar adalah pemberian air kelapa $300 \mathrm{ml}$ dan panjang stek $10 \mathrm{~cm}$.
\end{abstract}

\section{Kata kunci : Arachis pintoy, air kelapa dan panjang stek}

\begin{abstract}
Arachis pintoy can be reproduced in generative but also vegetative way, for example through cuttage. Problems arising from this reproduction method is the difficulty to form roots. The success rate of this method depends significantly on the size of the formed callus. To analyze the content of nutrients contained in the cuttage stem, we have to cut off the stem. And then it's necessary to find out additional factors that can influence the forming of the callus with a large percentage of rooting. One alternative solution is the provision of coconut water which believed to contain a variety of nutrients and growth substances. Therefore, we conducted a study to find out the interaction of these two factors on the growth of Arachis pintoy The purpose and goal of this research is to study and identify the growth Arachis pintoy which treated with coconut water its influences on the stem length. This research has been performed in Agrostology Lab of Animal Husbandrys Faculty of Sam Ratulangi University, during a period of 60 days. The research materials consists of Arachis pintoy, Coconut Water and soil. While the research method use 2 experimental factors: Factor A is the Coconut water, Factor B is the after-cuttage-stem length of Arachis pintoy, which arranged through completely randomized design (CRD). Each factor consists of 3 treatments, which repeated 3 times. These factors are as follows: $\mathrm{A}=$ volume of Coconut water, $\mathrm{A} 1=100 \mathrm{ml}$ of coconut water, $\mathrm{A} 2=200 \mathrm{ml}$ of coconut water, and A3 $=300 \mathrm{ml}$ of coconut water. Factor B $=$ stem length of Arachis pintoy, $\mathrm{B} 1=10 \mathrm{~cm}$, $\mathrm{B} 2=15 \mathrm{~cm}$, and $\mathrm{B}_{3}=20 \mathrm{~cm}$. And the variables which measured in this study were plant height, dry weight of roots and the roots volume. The results showed that administration of coconut water and the length of
\end{abstract}


the cuttings as well as the interaction of two factors give significant effect $(\mathrm{P}<0.05)$ to the growth of the number of leaves and root dry weight of the Arachis pintoy. Furthermore, coconut water does not give effect to the root volume and a combination of two factors do not impact on the growth of plant height. From the data analysis and discussion for all variables in this study, we can conclude that the best combination of growth in the number of leaves, dry weight of roots and root volume is the provision of $300 \mathrm{ml}$ of coconut water and $10 \mathrm{~cm}$ stem length.

\section{Keywords: Arachis pintoy, coconut water and stem length}

\section{PENDAHULUAN}

Hijauan sebagai pakan, besar manfaatnya terutama bagi bagi ternak ruminansia. Tersedianya hijauan berkualitas baik dan berkesinambungan sangat mempengaruhi perkembangan peternakan. Dengan demikian perlu dilakukan pemilihan jenis makanan ternak yang dapat tumbuh baik pada berbagai musim,cepat menutup tanah dan berproduksi tinggi.

Arachis pintoy termasuk ke dalam jenis hijauan tahunan, memilki tipe pertumbuhan dimana pada bagian pucuknya tumbuh terus, selalu menjalar rhizoma sehingga mampu bertahan tumbuh meskipun pada tanah-tanah yang relatif kurang subur .

Aracis pintoy dapat diperbanyak dengan stek batang. Umumnya ukuran stek batang leguminosa yang sering digunakan adalah $20-25 \mathrm{~cm}$ atau mengandung 2 buah buku. Permasalahannya apakah ukuran stek berlaku pada tanaman Arachis pintoy yang memilki batang berkayu lunak dimana tingkat pembentukan kallus lebih cepat. Untuk melihat terbentuknya ke kallus maka dilakukan variasi pemotongan stek. Keberhasilan stek membentuk akar tergantung pada besar kecilnya daya pembentukan kallus yang terdapat di bagian bawah stek. Kallus ini terbentuk karena adanya peranan hormon auxin tanaman. Air kelapa sebagai zat pengatur tumbuh alami merupakan salah satu alternatif karena mudah didapat, murah namun efektif (Purdyaningsih, 2015). Tujuan penelitian adalah untuk mempelajari dan mengetahui pengaruh pemberian air kelapa dan panjang stek terhadap pertumbuhan tanaman Arachis pintoy.

\section{METODE PENELITIAN}

Peneltian ini telah dilakukan di Laboratorium Agrostologi Kampus Fakultas Peternakan Unoiversitas Sam Ratulangi Manado Lamanya penelitian 60 hari.

Materi penelitian hijauan Arachis pintoy, air kelapa dan tanah. Perlengkapan : polybag dengan diameter $10 \mathrm{~cm}$ dan tinggi $14 \mathrm{~cm}$, timbangan analitik, gelas ukur $1000 \mathrm{ml}$, mistar, jangka sorong, plastik transparan, oven, ember plastik.

Metode penelitian menggunakan percobaan faktorial dengan 2 faktor A adalah air kelapa dan faktor B adalah stek tanaman Arachis pintoy yang disusun rancangan acak lengkap (RAL). Masingmasing faktor terdiri dari 3 perlakuan dan diulang 3 kali. Faktor tersebut adalah sebagai berikut:Faktor $\mathrm{A}=$ ukuran air kelapa A1 $=100 \mathrm{ml}$ air kelapa; A2 $=200 \mathrm{ml}$ air kelapa; dan $\mathrm{A} 3=300 \mathrm{ml}$ air kelapa sedangkan Faktor $\mathrm{B}=$ Panjang stek Arachis pintoy ; $\mathrm{B} 1=10 \mathrm{~cm} ; \mathrm{B} 2=15 \mathrm{~cm}$ dan $\mathrm{B}_{3}=20 \mathrm{~cm}$. Variabel yang diukur pada penelitian ini adalah pertambahan tinggi tanaman, pertambahan jumlah daun, berat kering akar dan volume akar.

\section{Prosedur Percobaan}

Sebelum dimasukkaan dalam polybag terlebih dahulu tanah dan air dianalisa. Selanjutnya tanah dicampur dengan air kelapa. Banyaknya air kelapa sesuai dengan perlakuan. Tanah yang sudah dicampur dengan air kelapa dimasukkan dalam polybag, setiap polybag diisi $3 \mathrm{~kg}$.

Stek tanaman Arachis pintoy diambil dari kebun percobaan Laboratorium Agrostologi dan stek ditanam dalam polybag masing-masing dua batang dengan kedalaman yang masuk ke tanah tujuh centimeter.

Pengukuran variabel tinggi tanaman, jumlah daun dan panjang daun dilakukan seminggu setelah ditanaman. Sedangkan pengukuran berat kering akar dan volume akar dilakukan setelah tanaman dipanen pada umur 60 hari.

\section{HASIL DAN PEMBAHASAN}

\section{Pengaruh Perlakuan terhadap Pertambahan Tinggi Tanaman}

Rataan perlakuan terhadap pertumbuhan tanaman Arachis pintoy yang akan dituinjukkan tabel 1.

\begin{tabular}{|c|c|c|c|c|}
\hline \multirow{2}{*}{$\begin{array}{c}\text { Panjang Stek } \\
(\mathrm{Cm}) \mathrm{B}\end{array}$} & \multicolumn{3}{|c|}{ Faktor (A) air kelapa (ml) } & \multirow{2}{*}{ Rataaan } \\
\hline & $\mathrm{A} 1(100$ & A2 (200) & A3 (300) & \\
\hline B1 (10) & 10.34 & 10.17 & 12.67 & $11.06^{\mathrm{a}}$ \\
\hline B2(15) & 9.82 & 11.43 & 12.85 & $11.37^{a}$ \\
\hline $\mathrm{B} 3(20)$ & 8.23 & 9.18 & 8.57 & $8.66^{b}$ \\
\hline Rataan & $9.46^{\mathrm{a}}$ & $10.26^{a b}$ & $11.36^{\mathrm{b}}$ & \\
\hline
\end{tabular}
perbedaan yang nyata 
Hasil analisis keragaman interaksi antara aik kelapa dan panjang stek dan panjang stek memberikan pengaruh yang tidak nyata $(\mathrm{P}>0.05)$ terhadap panjang tanaman. Hal ini berarti setiap kombinasi memberi pengartuh yang sama terhadap tinggi tanaman. Pemberian air kelapa berpengaruh nyata $(\mathrm{P}<0.05$ terhadap tinggi tanaman. Hasil uji BNT dieroleh hasil bahwa A1 berbeda tidak nyata $(\mathrm{P}>0.05)$ dengan perlakuan A2 tetapi berbeda nyata dengan perlakuan A3.

Selanjutnya perlakuan A2 bebeda tidak nyata $(\mathrm{P}>0.05)$ dengan perlakuan A3. Hal ini berrarti pemberian air kelapa sebanyak $200 \mathrm{ml}$ tidak berpengaruh nyata terhadap pertambahan tinggi tanaman atau jumlah tersebut sudah terwakilki 100 $\mathrm{ml}$ dan $300 \mathrm{ml}$ air kelapa untuk merangsang sel-sel tanaman sehingga dapat memanjang. Utami (2011) menyatakan zat pengatur tumbuh akan efektif dalam jumlah tertentu, dan pemberian zat tumbuh diatas batas optimum menjadi tidak efektif terhadap stek dalam merangsang pertumbuhan tanaman.

Panjang stek berpengaruh nyata lebih tinggi $(\mathrm{P}<0.05)$ terhadap tinggi tanaman. Dari uji BNT diperoleh hasil bahwa perlakuan $\mathrm{B} 1$ berbeda tidak nyata $(\mathrm{P}>0.05)$ dengan perlakuan B21 tapi perlakuan $\mathrm{B} 1$ berbeda nyata $(\mathrm{P}<0.05$ dengan perlakuan $\mathrm{B} 3$. Terlihat adanya kencenderungan tinggi tanaman diikuti oleh panjang stek dan terlihat adanya penurunan tinggi tanaman dengan semakin panjang ukuran stek. Pada percobaan ini rataan tinggi tanaman yang tertinggi dicapai pada perlakuan panjang stek $15 \mathrm{~cm}$ yang menghasilkan tinggi tanaman $11.37 \mathrm{~cm}$, kemudian $10 \mathrm{~cm}$ dan $20 \mathrm{~cm}$. Adanya kecenderungan penurunan panjang tanaman dari ukuran stek 20 $\mathrm{cm}$, hal ini lebih disebabkan kandungan karbohidrat yang terdapat pada stek $20 \mathrm{~cm}$ lebih banyak terbawa keudara melalui proses transpirasi sehingga untuk membentuk sel-sel yang baru tidak terpenuhi. Karbohidrat yang terdapat dalam jaringan tanaman akan membentuk energi. Pembentukan jaringan yang terjadi pada perkembangan jaringan primer, memerlukan karbohidrat yang berfungsi untuk penebalan dinding sel, pelindung pada epidermis batang dan perkembangan pembuluh baik dibatang maupun diakar jika suatu tanaman membentuk selsel baru pemanjangan sel pembentukan daun serta sistem perakarannya sangat membutuhkan pemakaian karbohidrat (Harjadi,1979). Pengaruh Perlakuan terhadap Pertambahan Jumlah Daun. Pertambahan jumlah daun A.pintoy terlihat pada Tabel 2.

Adanya interaksi pemberian air kelapa dan panjang stek terhadaap jumlah daun A.pintoy. Kombinasi daun tertinggi diperoleh pada perlakuan A2B1 (36 helai). Hal ini dapat diasumsikan stek berukuran 10 $\mathrm{cm}$ lebih cepat menyerap zat makanan zat nutrisi yang
Tabel 2. Rataan Pengaruh Perlakuan Terhadap Pertambahan Jumlah daun per Minggu Selama Penelitian (Helai)

\begin{tabular}{lcccc}
\hline $\begin{array}{c}\text { Panjang Stek } \\
(\mathrm{Cm}) \mathrm{B}\end{array}$ & \multicolumn{2}{c}{ Faktor (A) Air Kelapa (ml) } & \multirow{2}{*}{ Rataan } \\
\cline { 2 - 4 } B1 (10) & A2 (200) & A3 (300) & \\
B2 (15) & $33^{\mathrm{abc}}$ & $36^{\mathrm{a}}$ & $24^{\mathrm{de}}$ & 31 \\
B3 (20) & $25^{\text {cde }}$ & $31^{\mathrm{abc}}$ & $35^{\mathrm{ab}}$ & 30 \\
Rataan & $29^{\text {cde }}$ & $30^{\mathrm{bc}}$ & $22^{\mathrm{e}}$ & 27 \\
\hline
\end{tabular}

Keterangan: Huruf yang tidak sama pada baris dan kolom yang sama menunjukkan perbedaan yang nyata

terkandung di dalam air kelapa. Purdyaningsih (2015) mengatakan air kelapa selain mengandung unsur sitokinin juga auxin serta bahan-bahan pembangun lainya seperti protein, lemak, karbohidrat, mineral dan berbagai vitamin. Sitokinin selain berperan dalam proses pembelahan sel juga memilki daya rangsang terhadap diferensiasi jaringan terutma dalam hal pembentukan pucuk (Wattimena,1987).

\section{Pengaruh Perlakuan Terhadap Pertambahan Berat Kering Akar}

Pertumbuhan tanaman didefinisikan bahwa pertumbuhan tanaman sebagai pertambahan dalam yang diukur berdasarkan berat kering dari tanaman seluruhnya maupun bagian-bagianya (Fisher ,1984). Rataan Pertumbuhan berat kering akar tanaman A.pintoy pada Tabel 3 .

Tabel 3. Rataan Pengaruh Perlakuan Terhadap Pertumbuhan Berat Kering Akar per Minggu Selama Penelitian (gram)

\begin{tabular}{lrrrr}
\hline Panjang Stek & \multicolumn{2}{c}{ Faktor (A) Air Kelapa (ml) } & \multirow{2}{*}{ Rataan } \\
\cline { 2 - 4 } (Cm) B & A1 (100) & A2 (200) & A3 (300) & \\
\hline B1 (10) & $0.070 \mathrm{c}$ & $0.127 \mathrm{a}$ & 0.063 & 0.087 \\
B2 (15) & $0.123 \mathrm{ab}$ & $0.099 \mathrm{c}$ & $0.133 \mathrm{a}$ & 0.188 \\
B3 (20) & $0.077 \mathrm{~d}$ & $0.103 \mathrm{~cd}$ & $0.105 \mathrm{abc}$ & 0.095 \\
Rataan & 0.090 & 0.110 & 0.100 & \\
\hline
\end{tabular}

Keterangan: Huruf yang tidak sama pada baris dan kolom yang sama menunjukkan perbedaan yang nyata

Pemberian air kelapa dan panjang stek serta kedua faktor memberikan pengaruh yang nyata $(\mathrm{P}<0.05)$ terhadap berat kering akar tanaman A.pintoy. Kombinasi A3B2 adalah yang tertinggi nilai berat keringnya yaitu sebesar 0.133 gram. Air kelapa selain berfungsi sebagai hormon juga mengandung unsur mineral yang sangat dibutuhkan oleh tanaman. Unsur $\mathrm{N}$ air kelapa sebesar $0.02 \%$ dan $\mathrm{N}$ yang terdapat dalam tanah sebesar $0.13 \%$. Untuk pertumbuhan optimal tumbuhan dibutuhkan $0.15 \mathrm{~N}$ dalam tanah. (Lakitan 1993). Pengaruh Perlakuan Terhadap Pertambahan Volume Akar Ratan pengaruh perlakuan terhadap pertambahan volume akar tersaji pada Tabel 4 .

Interaksi kedua faktor berpengaruh nyata $(\mathrm{P}<0.05)$ terhadap volume akar tanaman A.pintoy. A1b2 adalah interaksi tertinggi dengan demikian pemberian air kelapa $100 \mathrm{ml}$ sudah mampu meningkatkan volume 
Tabel 4. Rataan Pengaruh Perlakuan Terhadap Pertambahan Volume Akar per Minggu Selama Penelitian (cm)

\begin{tabular}{lcccc}
\hline \multirow{2}{*}{$\begin{array}{c}\text { Panjang Stek } \\
(\mathrm{Cm}) \mathrm{B}\end{array}$} & \multicolumn{2}{c}{ Faktor (A) Air Kelapa (ml) } & \multirow{2}{*}{ Rataan } \\
\cline { 2 - 4 } B1 (10) & $0.51 \mathrm{c}$ & $\mathrm{A} 2(200)$ & A3 (300) & \\
B2 (15) & $0.75 \mathrm{a}$ & $0.58 \mathrm{bc}$ & $0.59 \mathrm{bc}$ & 0.59 \\
B3 (20) & $0.67 \mathrm{ab}$ & $0.52 \mathrm{c}$ & $0.54 \mathrm{c}$ & 0.68 \\
Rataan & 0.090 & 0.59 & 0.61 & 0.58 \\
\hline
\end{tabular}

Keterangan: Huruf yang tidak sama pada baris dan kolom yang sama menunjukkan perbedaan yang nyata.

akar untuk merangsang pertumbuhan stek tanaman. terbentuknya sistim perakaran yang lebih baik akan menjamin pertumbuhan tanaman yang lebih baik pula karena mempunyai fungsi yang sanga penting yaiitu selain menyerap air dan menral sari dalam tanah juga sebagai alat bernafas bagi tanaman.

\section{KESIMPULAN}

Kombinasi yang terbaik untuk p pertambahan jumlah daun, berat kering akar dan volume akar adalah pemberian air kelapa $300 \mathrm{ml}$ dan panjang stek $10 \mathrm{~cm}$

\section{DAFTAR PUSTAKA}

Fisher N.M dan P.R. Goldworthy., 1984. Fisiologi Tanaman Budidaya Tropik. Gajah Press. Yokyakarta.

Harjadi,S.S. 1993. Pengantar Agronomi. PT. Gramedia. Jakarta

Lakitan B. 1993. Dasar-dasar Fisiologis Tumbuhan. PT Raja Grafindo Persada. Jakarta.

Mandang, J.P. 1993. Peranan air kelapa dalam kultur jaringan tanaman krisan. Program Pasca sarjana IPB. Bogor.

Purdyaningsih E. 2015. Kajian pengaruh pemberian air kelapa dan urine sapi terhadap pertumbuhan stek nilam. Balai Besar Perbenihan dan Proteksi Tanaman Perkebunan

Utami,M.W. 2011. Respons pemberian hormon tumbuh dan mikoriza terhadap pertumbuhan stek ramin. Bulletin kebun raya .Vol. 14, No.2.

Wattimena,G.A. 1987. Zat pengatur tumbuh. DITJEN Pendidikan Tinggi. Depdikbud. Jakarta 